\title{
DEDICATION/ ACKNOWLEDGMENTS
}

To my big brothers, Russ and Joe, who taught me that, no matter our circumstances, we can always seek ways to alter our consciousness and see and be in the world differently. They were rough times, but for opening my eyes to anime and Japan, I owe you my life. And my mother, Denise, for the unending support and imparting a love of reading and the written word. To my friend Chris, who approached an awkward, angry young man, fresh off the boat and itching for a fight, and just kept on smiling. For that, and teaching me to smile again, I owe you more than you know. To my mentors inside and outside the academy, David H. Slater, Anne Allison, and Yoshimi Shun'ya, who took me under their wing and encouraged me to think in new ways - as consciousness altering as anything that happened up north, but decidedly less dark and more disciplined. To Keiko, the only person I watch anime with regularly. You saw me at my worst and stayed. I am better for having met you, and knowing that we will watch anime again keeps me going. While this project occupied me for many, many years, and often pulled us apart, know that I love you. And to those I came to know in Akihabara, for sharing your lives and stories, for showing me other worlds. Thank you. All of you, each and every one, I love. 
This page intentionally left blank 